\title{
SUSTAINABLE INTERDISCIPLINARY TRANSFORMATION OF WARSAW UNIVERSITY OF TECHNOLOGY BUILDINGS. KODNZEB CASE STUDY
}

\author{
E. RYNSKA, U. KOZMINSKA, A. ONISZK-POPLAWSKA, D. SZUBERT-KLINOWSKA \& A. TOFILUK \\ Faculty of Architecture, Warsaw University of Technology, Poland.
}

\begin{abstract}
Sustainable development has by now become an element deeply integrated in everyday design. The main difficulty is not the design of a new building but transformation and modernization of existing ones. Warsaw University of Technology (WUT) is one of the oldest universities in Poland, its building dating back to the beginning of the twentieth Century. It is spread over several sites most of which both the urban layout as well as many buildings - are under the care of historic preservation authorities. This substance should in the future years become one of the basic issues fulfilling Effective Energy Directive - lowering of the energy needs in the construction sector. This procedure is much easier when dealing with new buildings, not those existing and undergoing modernization. In 2015, a Nordic Finance Mechanism project for the nZEB technology transfer from Norway to Poland was awarded to a group of researchers from WUT and NTNU Trodheim. The main aim of the project is implementation of nZEB knowledge in Poland, as well as the preparation of two integrated concept designs for public (University) buildings as exemplary case studies that could act as benchmarks for other public buildings. The transfer of technology is not easy, both due to economic limitations, as well as different technical requirements, which have to correspond with Polish Building Codes. The other issue being that the Integrated Design Process is not very much used in Poland and, therefore, procedures and management of the project will form part of the transferred know-how. The benchmark public buildings belong to WUT - one is a student dormitory, the other houses the Faculty of Building Services, Hydro and Environmental Engineering. Both buildings date back to the 1970s. The outcomes of the project will also include the compilation of a Proceedings Manual dedicated to possible public investors showing an Integrated Road Map, including legal, financial and technical issues - and allowing choosing a best-case scenario. Training workshops are also foreseen within the project - they will take place in different parts of Poland and will start with a 'train the trainers' meeting, who in turn will be able to implement knowledge in other regions than just Warsaw. We also hope that we will be able to secure a construction grant - for the modernization of at least one of the chosen buildings.
\end{abstract}

Keywords: sustainable modernization of academic campuses, transfer of sustainable technologies and processes.

\section{INTRODUCTION}

Starting from the end of the twentieth Century it became obvious that most of the existing building stock in Poland is in need of major redevelopment. It was then for the first time that researchers of various disciplines from Warsaw University of Technology (WUT) working within sustainable development issues in the design and construction sector started cooperation with Norwegian University of Science and Technology (NTNU) assisted by research institute SINTEF. Cooperation started in 2002-2005 with 'Sustainable Rehabilitation of Buildings' - SURE-BUILD financed by R\&D Programme established by Norwegian Ministry of Foreign Affairs. Within the general framework, school buildings were chosen as a case 
study and detailed analysis. Cooperation was continued in years 2006-2011 with 'Thermomodernisation of public buildings conducted in accordance with the conditions of sustainable development - STEP', and was based on the fact that at the time Poland had no experience in energy assessments. This problem was then very urgent as EU members were obliged to implement Energy Performance of Buildings Directive (EPBD). The project was financed by EEA Financial Mechanism and the Norwegian Financial Mechanism.

The recast of EPBD [1] requires that from 2019 all new buildings occupied and owned by public authorities are nearly zero-energy buildings (nZEB), and by the end of 2020 all new buildings should also have the same status. Hence, this current project 'Design retro-fit nZEB concept for two buildings - KODnZEB', which is also the subject of this article, aims to formulate a response to this new challenge. The project will continue cooperation between WUT and NTNU until May 2017. This time, the basic aim is to develop an interdisciplinary step-by-step management in case of providing nZEB modernization procedures for existing buildings. We hope to successfully transfer both Norwegian know-how as well as the technology itself. However, experience from previous projects proves that every transfer has to include a 'made to fit' aspect based on the joint knowledge of researchers from various disciplines and countries.

\section{CASE STUDIES}

The contemporary urban and architectonic features of the WUT complex are the outcome of the after-war rebuilding process and construction of various new buildings. Main interventions within historic buildings were triggered by inadequate space to house growing teaching and academic requirements. This oldest part of the WUT complex, listed as part of a historic heritage is a good example of changing modernization and preservation approaches. The after-war rebuilding process was in fact more in favour of modernization than reconstruction of historic forms. Main emphasis was placed on efficiency and intensification requirements - not on reconstruction of historic forms. Mid-half of the twentieth Century and its architectonic socialistic realism ideas, were in fact based on Renaissance and Classical solutions. Buildings built in the 1960s were a reaction against this forced architectonic trend. The only restriction in free creation of building forms were inadequate technical skills and the low quality of materials used. This attitude pushed all historic integration ideas into a further plane. Close of the 1970s brought new attitudes that concentrated on the analysis of existing substance and new proposals, as well as on provision of expected user needs. The last years of the former decade, especially after receiving EU member status and possibility to draw on international funds, were filled with revalorization works on remaining historic buildings. Additionally, the WUT management requested an urban and architectural analysis that showed which buildings could be extended and which plots could be invested in.

Prior to the start of KODnZEB, the research team and WUT management representatives analysed the possible choices. Buildings proposed as case studies differ in type, time of construction and used technologies.

The first chosen site is a Dormitory Building Muszelka (Shell), one of the student housing buildings located in Narutowicza complex in Warsaw [2]. This original student social housing dates back to 1922, when site between Grojecka, Mochnackiego, Uniwersytecka and Narutowicza Square was given the status of Academic Colony. A well-known architect of the time, K. Tolloczko, was chosen as the leading designer. It was then planned that the Colony would consist of housing pavilions, a kitchen and canteen facilities, swimming pool, gym area, student's club, library, health buildings and student organization offices. Three dormito- 
ries were built before 1939 (Bratniak, Pineska and Akademik). These formed an 'U' shaped complex with internal courtyard which were completed only in 1950 (arch. Z. Dytkowski) according to the original design assumptions from 1922. It should be noted that the described buildings very likely from the oldest Polish student dormitory complex. The first and the most interesting is the Akademik Building. In fact, the word 'academic', which is commonly used in Poland instead of 'hostel' is derived from the name given to that building. The site where Academic Colony is situated is subject to a valid Master Plan, which will undergo changes within the next few years due to a modernization of the adjacent public square area and emphasis to create a new quality of life within the busy public city area. During World War II, this complex was used by the Nazis, who located a prison in the basement area. Those who died there are listed on a stone tablet dedicated to their tragic memory.

DS Muszelka is four stories high, with one underground level. It houses 150 students. The main load-bearing elements are reinforced concrete, full ceramic brick walls with no insula-

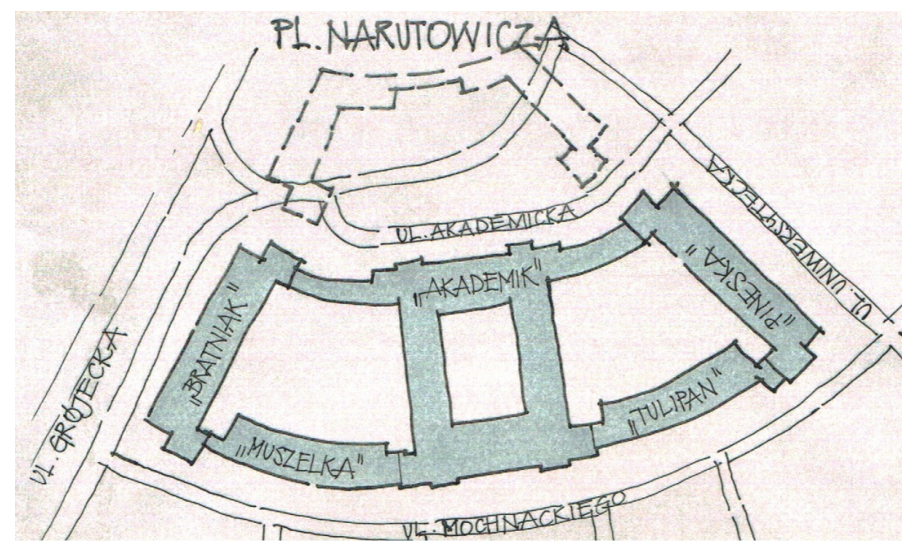

Figure 1: Schematic layout of Academic Colony, dotted line indicates extension, planned but never constructed [authorship: Tofiluk A].

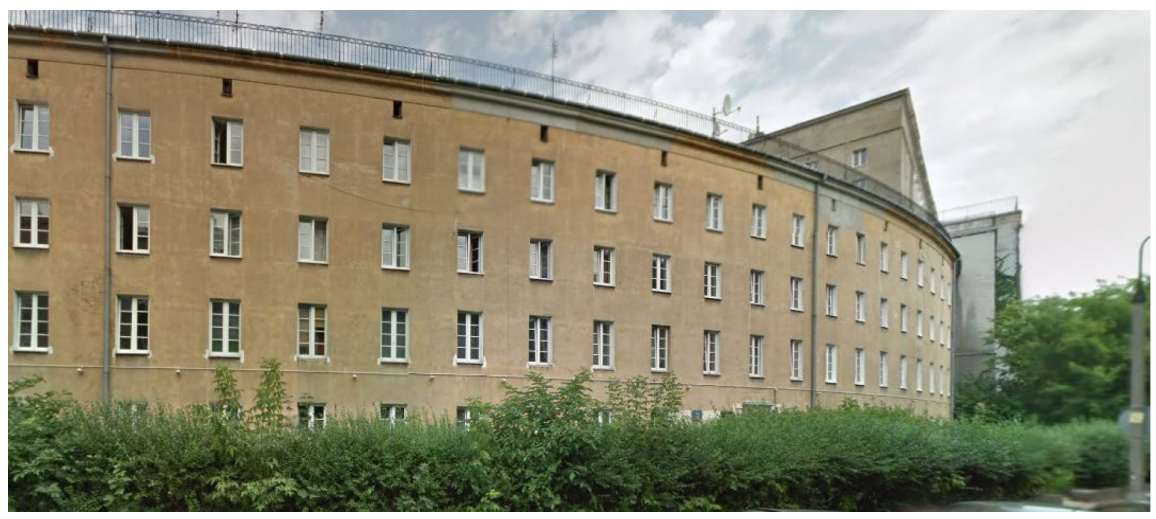

Figure 2: Muszelka Building, facade off Małachowskiego Street [authorship: Tofiluk A]. 

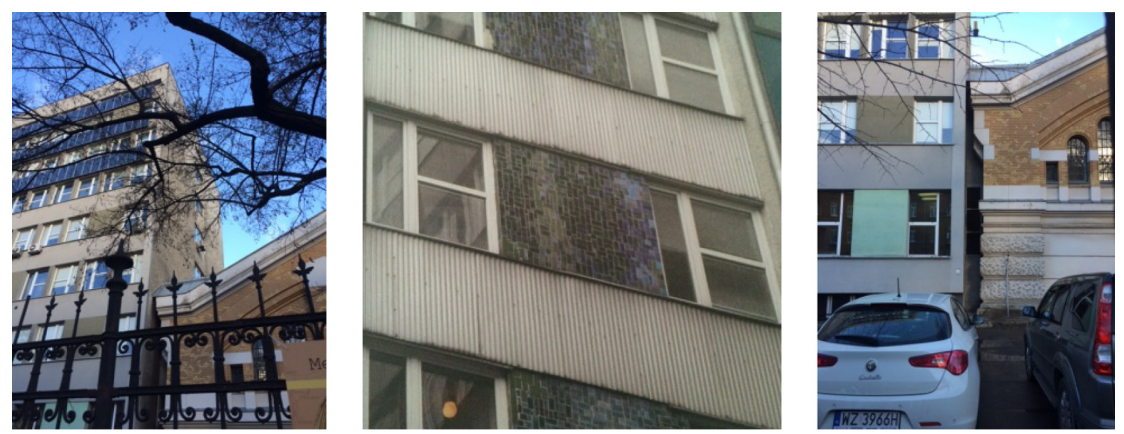

Figure 3: Environmental Engineering Building with a mosaic façade and a neighbouring historic Old Boiler House Building, WUT [authorship: Tofiluk A].

tion. Building forms an in-fill between two other hostels. It was built in the 1950s and modernized duirng the late 1980s. Roof was insulated and window framework was exchanged in the late 1990s. The architecture characteristic of this complex is monumental but modest with predominant simplified classical features. Detail is scarce, especially on the buildings constructed after 1945. Muszelka fits into the initial urban context, and basically follows the site ownership lines. Hence, the south and north facades are curved forming a street line. It can be summarized that the urban layout is much more interesting than the architectonic features used. Possibly that is the reason why this area is listed as valuable urban historic surroundings.

The second site is the seat of the Environmental Engineering Faculty located in the main campus area, which is also listed as a historic preservation zone [2]. Nevertheless, the building itself is not under conservationist care as its location was initially pointed out as a potential place for development only in 1955 and the building was constructed in the 1970s based on a design by S. Jaczewski and J. Reda. It is ' $\mathrm{L}$ ' shaped, forming an internal atrium open against the existing historic building. The wing located parallel to the street is 8 stories high, and the other one has 11 levels. It is used on everyday basis by different groups of students (app. 2,000 people). The main load-bearing elements are in reinforced concrete, monolithic in the basement level and prefabricated framework skeleton elements on the upper floors. Slabs are also prefabricated. Its architecture forms a strong contrast with the surrounding historic eclectic buildings that date back to the beginning of the twentieth Century. In fact, this modernistic building has no architectural linkage with existing historic details, as it was purposely designed to form a contrast both in scale as well as in the choice of tectonics. When constructed, the detail was decorative mosaic panelling in various shades of blue. In 2007, after the last modernization, elevation was insulated and mosaics were mostly hidden behind solar photovoltaic batteries.

Chosen site echoes with issues concerned with repeatable architectural forms due to main ideas of those times - standardization and prefabrication - which unfortunately also included low technical and construction standards, non-existence of adequate funding and management of investments.

\section{THE PROCESS}

The main aim of the project is formulation of procedures for pilot retrofitted buildings. It includes information on verification of technical installation performance and demonstrates 
testing of holistic solution on a building case including transfer of Norwegian technical and procedural knowledge

The first task of the design process was to provide a common definition of nZEB for the KODnZEB project based on primary energy factor (PEF) value [3]. According to EPBD Recast: 'nearly zero-energy building means a building that has a very high energy performance' and 'energy required should be covered to a very significant extent by energy from renewable sources'. The nZEB standard is achieved when the PEF value is higher than that in a zero-energy building and lower than that in a building, which meets minimum requirements. In this project, an nZEB building was defined as the one that meets $90 \%$ of the requirements for a zero-energy building. Thus, PEF values for nZEB are:

- for collective dwelling building (without cooling): $9.5+5.0 \mathrm{kWh} / \mathrm{m}^{2} /$ year.

- for collective dwelling building (with cooling): $9.5+5.0+2.5 \times \mathrm{A}_{\mathrm{f}, \mathrm{c}} / \mathrm{A}_{\mathrm{f}} \mathrm{kWh} / \mathrm{m}^{2} /$ year.

- for public use building (without cooling): $6.5+10.0 \mathrm{kWh} / \mathrm{m}^{2} /$ year.

- for public use building (with cooling): $6.5+10.0+2.5 \times \mathrm{A}_{\mathrm{f,c}} / \mathrm{A}_{\mathrm{f}} \mathrm{kWh} / \mathrm{m}^{2} /$ year. where $A_{f}$ - heated usable area, $A_{f, c}$-cooled usable area

The energy balance is calculated yearly for the whole building (the outer façade with installations is accepted as the building's limit) and includes primary energy from heating, cooling, ventilation, warm water heating, lightening and auxiliary energy. Calculations are made in accordance with PN-EN 137900 and with the use of Design Builder Software.

After defining the nZEB standard, usage profiles were created and available technologies were analysed. Several European case studies were examined to encourage the WUT buildings' renovation. The aim of the majority of investigated modernization projects was to meet current energy, safety and fire resistance standards. Moreover, their programme, layout and aesthetics needed to be improved. Various solutions were used to achieve a better energy standard. The most common practice was to place a layer of insulation on the outer side of the building's external wall and cover it with plaster or other cladding [4]. Sometimes, mostly due to historic conservation requirements, insulation was added inside. More complex examples include the addition of curtain walls [5] loggias, balconies [6] shutters and other elements [7]. Extensions were introduced to improve living conditions and to increase floor area [8]. Spatial rearrangements done within an existing structure include demolition of partition walls or the use of movable systems. New elements often significantly improve a building's appearance. External additions can highlight the details of original elevations or may be designed as a second skin, which screens dilapidated buildings. Additions are attached to an existing structure or are designed as independent, self-supporting elements. The second solution is safer as the load-bearing capacity of old structures is often limited. At times, new forms are provided to highlight the entrance (e.g. glass cubes as vestibules to Europarei Housing or concrete boxes leading to Panelaky building) or to introduce a new function (e.g. a transparent cube with a café in Darmstadt college). Moreover, thermo-modernization requires old windows, doors and installations to be exchanged to ensure an adequate energy standard. Legibility and aesthetics of interior space can be improved by the replacement of materials and lighting equipment or by the use of specific colours.

Three projects, analysed during the research process, can be defined as particularly relevant and inspiring for the modernization of WUT buildings, which are: an office complex in Oslo, a student housing in Munich and a college building in Darmstadt. The first one Powerhouse Kjobro [9], a 5,200 $\mathrm{m}^{2}$ office, building from the 1980s, was redesigned in 2014 

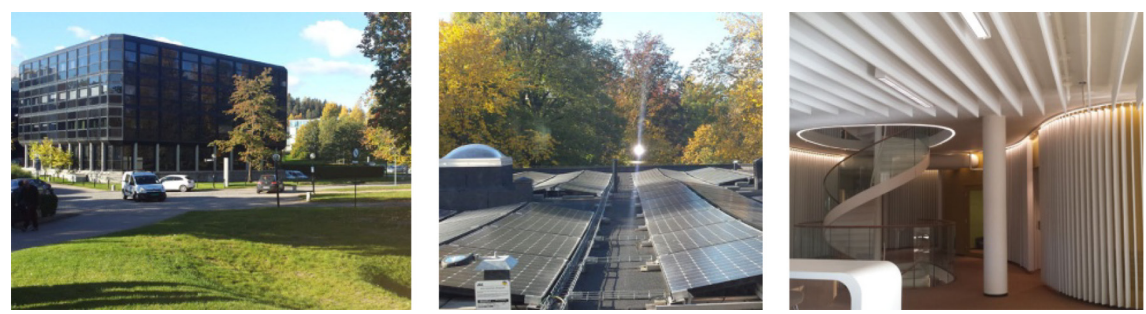

Figure 4: Powerhouse Kjobro, Oslo [authorship: Ryńska E.D].
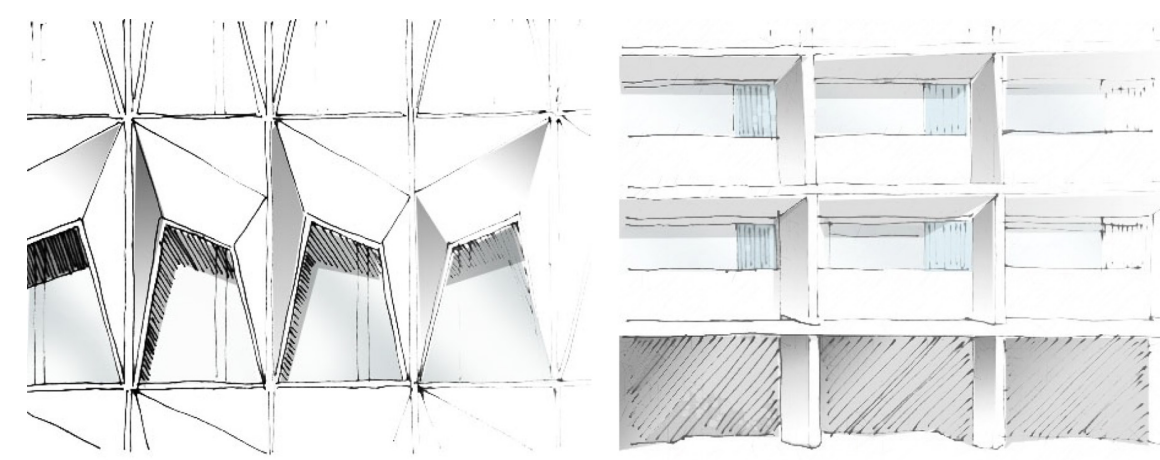

Figure 5: Façade of a student housing in Munich and academy in Darmstadt [authorship: Kozminska U].

by Snohetta. This pilot project, led by Norwegian Research Centre on Zero Emission Buildings, produces more energy than it consumes. The energy balance is calculated for the whole lifespan of the building (i.e. for the next 60 years). The total energy demand was reduced by $80 \%$. Highly insulated walls, windows with good insulation performance, limited thermal bridges, resulted in a good thermal performance of the building's envelope. Photovoltaic modules placed on the rooftop produce more energy for electricity $(200,000 \mathrm{kWh} / \mathrm{year})$ than the building requires. In comparison, ventilation, lighting, heating and cooling requires $145,000 \mathrm{kWh} /$ year. Ventilation preheating, cooling and water heating in the building are run on geothermal energy. Lighting, fans and materials are optimized to reduce energy consumption. Moreover, energy losses are taken into consideration when calculating PEF. Thus, a holistic project of Powerhouse Kjobro exceeds the nearly zero-energy standard but - to some extent - can be instructive for the KODnZEB project in Warsaw.

Another inspiring example of modernization is a refurbished skyscraper with student housing in Munich. It was designed in 1969 by G. Eckert as part of a Olympic village complex. During the renovation, the building's appearance and technical properties were improved to meet current energy and safety standards in Germany. Monumental and outdated façades of the $29,000 \mathrm{~m}^{2}$ student housing were redesigned - unused loggias were closed to increase usable floor space. Every student unit was enlarged from 11.66 to $14.22 \mathrm{~m}^{2}$, which was necessary to meet current standards relevant to a minimum student living space $\left(13 \mathrm{~m}^{2}\right)$. Each flat was rearranged to separate the sleeping and working area from the kitchen and bathroom. New façades were made of light, prefabricated, concrete panels and insulated with mineral wool. The character of the original façades was preserved in a geometrical form of new ele- 
ments. Their tectonics was enhanced by the use of new aluminium windows and sills. A layer of new insulation and cladding enabled achievement of an energy standard KfW 100 (with primal energy demand $12.68 \mathrm{kWh} / \mathrm{m}^{2}$ and final energy demand $-53.6 \mathrm{kWh} / \mathrm{m}^{2}$ ). Further, the cost of heating was reduced and acoustic conditions were improved by the use of new suspended ceilings, floating screeds and partition walls. Legibility of the floor plan was enhanced by the use of colour in interiors (on floors, ceilings, doors and furniture). Architectural solutions from this project can be used as guidelines for modernization of WUT buildings.

Finally, the project in Darmstadt is an example of a successful transformation of degraded educational building, which was similar to the Faculty of Environmental Engineering in Warsaw. The C10 college building was built in 1965 and renovated in 2011 to meet current energy and fire resistance standards. Further, the functionality of the building needed to be improved. The floor plan was organized around the central core with two staircases, elevators and technical spaces. Office rooms were added in the southern part of the building. Lecture, seminar and laboratory rooms were located on the northern side. Glass cubes with a café and auditorium were introduced in the ground floor. Claddings of internal walls, floors and ceiling were replaced with new materials and coloured elements were placed inside to improve the legibility of the floor plan. The biggest change is visible from the outside - a cubical and outdated high-rise building disappeared under a modern and aesthetic façade cladding. This outer shell was introduced to improve energy parameters and light conditions. Various features and functions were integrated into the building's second skin design. Thus, elevations differ. The northern one, which is visible from the city, received new openings and simple pilasters. The east and west façades gained vertical, metal reliefs, which enhanced the slenderness of the building. The southern one was covered with a three-dimensional structure. These modules were designed to fit the rhythm of the existing windows and to create optimal lighting conditions. The shape of asymmetrical panels was discussed with the environmental engineering company Transsolar. The goal was to protect the rooms from overheating while enabling daylight to enter. Modular façade panels $(1.87 \times 3.87 \mathrm{~m})$ were made of two layers of folded aluminium with a void inside. Their surface was perforated in the bottom part of the lintel to enable ventilation of the facade. Sculptural structure breaks the monotony of the former elevations. Similar solution could be used for the modernization of the Faculty of Environmental Engineering in Warsaw.

\section{CONCLUSIONS: GUIDELINES FOR KODNZEB PROJECT}

The analysis of selected projects provided valuable information for the modernization of both WUT buildings - student housing 'Muszelka' and the Faculty of Environmental Engineering. The first one, built in the 1950s, is part of the historic complex. Its simple architecture remains synchronous with the surrounding buildings. Thus, respect for the existing form is necessary and modifications should be integrated with changes in other academic buildings. However, the renovation of the rest of the complex has not yet been planned. In order to proceed, designers should manage their work based on a document containing Integrated Design Procedures worked on a few years ago by some team partners [10]. According to an energy audit, in DSM 'Muszelka' a 14-cm thick layer of mineral wool should be placed on the external walls and $21 \mathrm{~cm}$ at the roof to improve thermal conditions in the building. It is recommended that thermo-modernization does not change the appearance of the building. Thus, necessary insulation should be added on the inner side of the external walls - insulation of the basement can be placed on the exterior. No major aesthetic changes will be done to façades. The structure remains untouched. Windows were changed and their performance was good but new diffusers should be added in student rooms. The transformation of the inside of the building 
will be more complex. All installations have to be replaced with new systems. Poor quality flooring and wall claddings can be substituted with new materials. Better quality furniture should be provided in student units and kitchens. Some aesthetic improvements (e.g. colourful elements) may be done in shared spaces.

The Faculty of Environmental Engineering, built in the 1970s, is a significantly different case than student housing 'Muszelka' - an L-shaped building consisting of two massive, cuboidal blocks, which are in strong contrast with those in the neighbouring, historic university campus. This contradiction is enhanced by poor technical condition and questionable aesthetics of façades. Last renovation works included thermal insulation of the roof of the lower building, replacement of old windows, installation of photovoltaic panels on the southern façade and some changes in the interior. Unfortunately, new elements do not improve the architecture of the faculty. Energy audit showed that a 16-cm thick layer of mineral wool should be placed on the façades and $18 \mathrm{~cm}$ on the roof of the higher building. However, necessary modernization should not be limited to thermal insulation. The visual perception of old façades and the building's technical condition should be improved and the linkage of the faculty with picturesque surrounding should be provided as well. Thus, a complex approach to modernization is recommended. Similarly, in the C10 college in Darmstadt, a second skin could cover the faculty building. Due to the limited capacity of the load-bearing system, the external shell should be designed as a self-sufficient structure. Alternatively, light, cladding panels can be used. Shading elements (e.g. sunshades, sun protection glass) may be added on the southern façade to protect from overheating. Some windows need to be replaced with

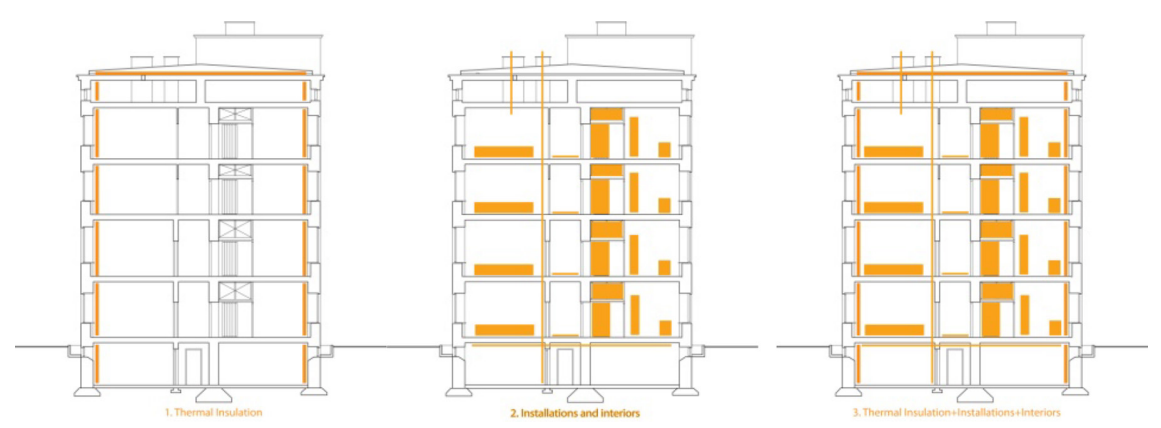

Figure 6: Student Housing Muszelka - the concept of modernization [authorship: Kozminska U].

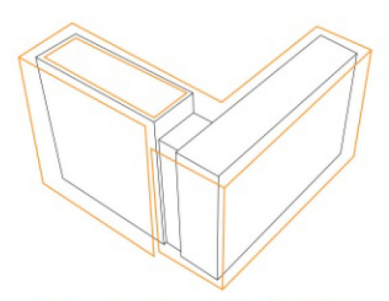

1. Thermal insulation+facade cladding

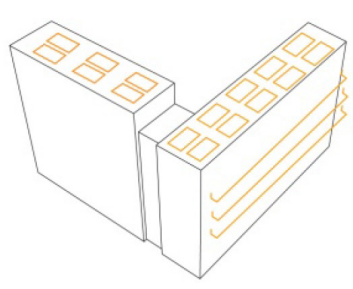

2. Photovolataic panels+sun protection

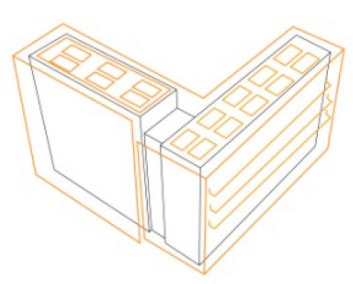

3. Thermal insulation+facade cladding +Photovolataic panels+sun protection

Figure 7: The Faculty of Environmental Engineering - the concept of modernization [authorship: Kozminska U]. 
those with a better insulation performance. More photovoltaic panels are required. All these elements should be integrated into a system that will create the outer shell of the building. However, the understanding of the shell is flexible - the materials and forms can vary on different façades but the overall system should be coherent and aesthetic. This consistency is also recommended for the interiors. Thus, some improvements should be made. The legibility and efficiency of the building's layout will be enhanced by minor spatial rearrangements (e.g. the use of flexible wall systems, some partition walls demolitions) or by the use of colour elements. Outdated and damaged materials should be replaced with new ones and the number of different finishing types should be limited.

Modernization of the Faculty of Environmental Engineering is a different and more complex project than the renovation of student housing 'Muszelka'. Both buildings require refurbishment, which is not limited to adequate insulation. Selected European case studies may be inspirational and a valuable source of knowledge for Polish projects [11]. However, Polish economic, environmental and social conditions vary from Norwegian and German conditions. Thus, a direct implementation of foreign solutions is not possible - the transfer of knowledge has to include a 'made to fit' aspect [12]. Project strategy, standards and materials should be chosen according to a specific local context and existing possibilities.

\section{REFERENCES}

[1] EPBD Recast, Directive 2010/31/EU of the European Parliament and of the Council o 19 May 2010 on the energy performace buildings (recast), Official Journal of the European Union, 2010.

[2] Wagner, A., Architektura Politechniki Warszawskiej Oficyna Wydawnicza Politechniki Warszawskiej, 2015.

[3] Mijakowski, M., Narowski, P. \& Sowa, J., Definicja budynku nZEB na potrzeby projektu KODnZEB, Warsaw, 2015.

[4] http://www.staab-architekten.com/, dn.3.02.2016.

[5] http://www.db-bauzeitung.de/db-metamorphose/projekte/studentisches-wohnhochhaus-in-muenchen/ dn.3.02.2016.

[6] Aparicio, S. \& Alonso, J., Reestructuracion de la vivienda social en Holanda: Caso Europarei, Uithoorn, de Architectura, nr. 27, 2012.

[7] http://www.baunetzwissen.de/objektartikel/Fassade-Hochhaus-C10-der-HochschuleDarmstadt_3086847.html,dn.3.02.2016.

[8] http://www.knererlang.de/, dn.3.02.2016.

[9] Salvesen, F., Powerhouse Kjobro-Renovation to plus energy standard, Asplen Viak AS, Company presentation for KODnZEB project, 2015.

[10] A Guide to Integrated energy design IED”. Guide published under joint care of representatives from Norway, Denmark, Greece, Poland, Austria and UK. Prepared as the outcome of an international Project INTEND Supported by Intelligent Energy Europe, 2008-2010, www.intendesign.com

[11] Petzet, M., Reduce, Reuse, Recycle: Rethink Architecture. German Pavilion, Hatje Cantz: Ostfildern, 2012.

[12] Rynska, E.D., Rehabilitation and Adaptive Reuse of Historic Buildings in Poland, co-author in Harmonisation between Architecture and Nature. Eco-Architecture II, WIT Press, 2008. 